\title{
Apresentação
}

\section{Ligia Chiappini}

Num país marcado pela falta de memória e num tempo em que se declara o fim da história, é gratificante constatar que, pelo menos em alguns setores, há pessoas que ainda se lembram não apenas dos textos que escreveram mas também dos textos que têm inspirado práticas transformadoras, na luta contra a corrente por uma sociedade mais justa e menos bárbara.

\section{A ASSOCIAÇÃO DOS PROFESSORES DE} LÍNGUA E LITERATURA é um espaço que se mantém com esse espírito, buscando congregar professores e pesquisadores que no plano da cultura sustentam essa luta. A APLL nasceu no bojo dos movimentos de reorganização da sociedade civil brasileira no final da ditadura e se fortaleceu como entidade cultural e politica durante as greves históricas de 1979 no ensino médio e superior. De lá para cá, com muitos percalços e muita garra, tem-se mantido fiel ao objetivo central que define sua especificidade: a integração entre professores que trabalham com os textos e a linguagem do maternal à Universidade, para, através de um diálogo mutuamente fecundante, desenvolver teorias e práticas que nos ajudem a resistir ao sucateamento do ensino, especialmente do ensino público.

Por seus encontros anuais, sua participação ininterrupta nos simpósios, mesas redondas, seminários, conferências e cursos da S.B.P.C., à qual é filiada desde o início (1978), e por sua revista, Linha d'Água, tornou-se conhecida e respeitada como uma entidade séria que contribui para a formação de professores e para a melhoria do ensino paulista e brasileiro. 
A relação da APLL com a SBPC é marca de origem a destacar, porque estimula, junto com a militância associativa, um esforço permanente de pesquisa e reflexão, facultando o acesso à pesquisa universitária aos professores de primeiro e segundo graus, geralmente considerados (e muitas vezes por eles próprios) como intelectuais subalternos. Por outro lado, estimula-se também os professores universitários a repensarem suas teses e as teorias em que se apóiam tendo em vista os problemas suscitados pelo trabalho com os textos e a linguagem no ensino dirigido a crianças e jovens. Problemas que precisam ser pensados na confluência de diversas áreas: LINGÜÍSTICA, TEORIA LITERÁRIA, LÍNGUA PORTUGUESA, LITERATURA BRASILEIRA, EDUCAÇÃO, PSICOLOGIA E COMUNICAÇÕES, entre outras.

Este número especial de Linha d'Água, composto pelos textos que foram lidos na Reunião da S.B.P.C. de julho de 1994, reafirma e aprofunda essa tradição. Reunindo resultados de pesquisa acadêmica em LÍNGUA PORTUGUESA, LINGÜÍSTICA, TEORIA LITERÁRIA E LITERATURA COMPARADA à contribuições da pesquisa aplicada ao ensino, este número cobre uma gama muito variada de temas que são de grande interesse para professores de lingua e literatura de todos os níveis: da gramática da língua falada e escrita e da produção do texto à sua leitura em sala de aula; destas a análises finas de autores brasileiros confrontados com a tradição nacional e européia e à teoria e prática da educação popular que, discutida nesse contexto mais amplo dos estudos da linguagem, ganha outra dimensão, já que usualmente se estabelece uma distinção quanto mais rígida mais empobrecedora entre ensino formal e informal. Relativiza-se assim tal dicotomia, de modo enriquecedor para a reflexão sobre o trabalho com os textos e a linguagem dentro e fora da rede escolar, com crianças, jovens e adultos, no campo e na cidade.

Novidade também são os primeiros resultados aqui apresentados a partir de uma pesquisa integrada sobre a circulação dos textos na escola, especialmente pela análise criteriosa dos dados obtidos em observações de aulas e estudo dos textos escritos ou lidos pelos alunos de 15 escolas paulistas. Destaque-se o espaço 
concedido nessa investigação aos livros didáticos e para-didáticos, à poesia e aos materiais não didáticos, ou seja, àqueles textos que, provindos dos veículos de massa, tais como o radio, a televisão, o vídeo game, o cartaz publicitário, entre outros, constituem uma espécie de discurso subterrâneo que, embora integre o repertório dos alunos e circule com eles na escola, não recebe desta o tratamento necessário, passando mesmo desapercebido na maior parte dos casos.

Finalmente, incursões teóricas sobre a problemática mais ampla do imaginário individual e social e um trabalho que, ao mesmo tempo, resume uma tese recente de doutorado e dela extrai conseqüências mais largas, sobre o teatro infantil e a formação do teatro brasileiro moderno, encerram este volume denso e tenso de informações, reflexão e experiência de pesquisa e docência.

Em 1981 a APLL lançou um livro, publicado pela editora Cortez, hoje esgotado, que se chamava Língua e Literatura, o professor pede a palavra. Eram as atas da sua participação na reunião da S.B.P.C. do ano anterior, cujo tema central era Ciência e Educação para uma Sociedade Democrática. Quase 15 anos depois, lança esta Linha d' Agua especial que oportunamente volta a lembrar de modo eloquente que ainda não se perdeu de vista a esperança de contribuir para a conquista da cidadania através da educação, da ciência e da arte. 